\title{
Proměny vztahu státu a ruské pravoslavné církve v postsovětském Rusku - vybrané problémy
}

\section{a témata*}

\section{Transformations of the Relationship Between the State and the Russian Orthodox Church in Post-Soviet Russia - Selected Issues and Topics}

\author{
Vladimír Naxera / vnaxera@kap.zcu.cz \\ Katedra politologie a mezinárodních vztahů, Západočeská univerzita v Plzni, Plzeň
}

\begin{abstract}
In this article the author tries to provide a basic outline of the forms and metamorphoses of mutual relations between the Russian orthodox church and the state in the period from the collapse of the USSR to the present day. At the latest since the mid-nineties began to realize the interactions between the two actors and the church has become (co-) creator of the new national/state ideology, which is typical for the current authoritarian regime V. Putin. The text shall be measured on the selected topics and events, on the basis of which it is possible to relationship illustrate. Among these selected examples will have a dominant position case Pussy Riot, which well shows the real interconnection and the creation of discourse, which this link legitimizes.
\end{abstract}

\section{Key words}

Russia, Russian Orthodox Church, patriarch, Jelzin, Putin, Pussy Riot, Kirill, Alexy II

Článek vznikl v rámci projektu SGS-2015-015, který byl poskytnut Západočeskou univerzitou v Plzni. Některé myšlenky a informace obsažené $\mathrm{v}$ textu byly již dříve publikované $\mathrm{v}$ textech, jejichž jsem spoluautorem, do tohoto textu byly převzaty s laskavým svolením spoluautorky - viz Avanesova, Maria a Naxera, Vladimír: Ruská pravoslavná církev a její vztahy se státem v době patriarchátu patriarchy Alexije II. Politické vedy, 2016, roč. 19, č. 3, s. 8-30, také Tíž: Proměny vztahů ruské pravoslavné církve v době patriarchy Kirilla. Central European Political Studies Review, 2016, roč. 18, č. 1, s. 84-100. 
Cílem předkládaného př́spěvku je poskytnout základní náčrt vztahu mezi ruskou pravoslavnou církví a státem v období po rozpadu SSSR. Zdůrazněna budou přitom specifika tohoto vztahu a to, jakým způsobem se daný vztah proměnil. Začátek devadesátých let přinesl díky pádu komunismu církvi zcela nové možnosti a výrazným způsobem změnil její postavení. Zásadním aktérem vztahů se od počátku stal patriarcha Alexij II., který se roku 1990 stal celkem pátým patriarchou ruské pravoslavné církve v období existence $\operatorname{SSSR}^{1}$ a zároveň patriarchou, do jehož volby výrazněji nepromlouval stát, což je jev, který není v rámci specifické ruské církevní historie př́liš častý. $\mathrm{V}$ počátečním období po rozpadu SSSR se vzájemný vztah státu a církve nesl spíše v duchu snahy státu o odčinění sovětské minulosti, která církev výrazně poškodila, a to samozřejmě nejen v období stalinském. Nejpozději v polovině devadesátých let se však vzájemný vztah začal proměňovat a ze státu a církve² se stali vzájemně provázaní aktéři. Tato vazba vydržela i přes změny na postu prezidenta i patriarchy dodnes.

Situace provázání státu a církve není z historického hlediska pro Rusko ničím novým a neznámým - vztah státu a církve se v rámci ruských dějin odvíjel odlišně od zbytku Evropy a nejpozději od doby vlády Petra I. můžeme pozorovat výrazné navázání církve na stát, což bylo dáno i zrušením úřadu patriarchy. Tato vazba se v období dalších carů ještě zvýraznila, z církve se de facto stala jedna z oblastí státní správy a v rámci ideologie ruského samoděržaví byla postupně vypěstována ona pověstná „symfonie moci“, tedy aliance moci světské a moci duchovní, ke které má současná Ruská federace opět velice blízko (srov. níže v textu). Dnešní provázanost obou aktéru je vzájemně výhodná - církev vyjadřuje oficiální politice ústy svých vysokých představitelů podporu, čímž jí dodává notnou dávku legitimity, stejně tak církev má díky tomuto vztahu zajištěné privilegované místo ve společnosti, médiích, školství atd.

O současném Rusku v žádném případě nelze hovořit jako o státu demokratickém Putinův režim lze dle mnoha odborníkủ ${ }^{3}$ směle označit za režim autoritativní. ${ }^{4}$ Putin sám přitom povahu režimu zastírá koncepty tzv. řízené nebo též suverénní demokracie, ${ }^{5}$ která má, namísto odmítaného západního modelu liberálně demokratického zrrízení, být pro Rusko ideální cestou. Jedním ze znaků autoritativních režimů je tzv. režimní mentalita, přičemž základem existujících mentalit bývá velice často církev či nábožen-

1 Předchozími byli Tichon, Sergij, Alexij I. a Pimen.

2 Pokud budu v tomto textu hovořit o „církvi“, budu hovořit o horních patrech církevní hierarchie v čele s patriarchou, respektive o oficiálním názoru církve. Jsem si přitom vědom skutečnosti, že řadoví duchovní, kláštery a celá řada dalších církevních aktérů může mít (a také v mnoha ohledech opravdu mají) na řadu témat odlišný názor, než oficiální vedení. Nicméně daný text vyhrazeným prostorem neumožňuje tyto rozdíly hlouběji zachytit. Zároveň se nedomnívám, že by tato skutečnost byla jakkoli problematická, nebot'záměrem textu je zkoumat názory právě zejména církevního vedení, které celou církev symbolizuje a v osobě patriarchy též personalizuje.

3 Např. Holzer, Jan: Nejistá demokratizace: př́pad ruské opozice. In: Rusko a Západ. Eseje o (ne)porozumění. Ed. J. Hanuš. Brno 2015, s. 97.

4 K povaze tohoto typu režimu srov. Linz, Juan: Totalitarian and Authoritarian Regimes. Boulder 2000.

5 Např. Leichtová, Magda: Pod maskou medvěda. Neporozumění ve vztazích Ruska a Západu po skončení studené války. Brno 2010, s. 113-115 nebo táž: Misunderstanding Russia: Russian Foreign Policy and the West. Farnham 2014. 
ství obecně. Tento stav platí i pro současné Rusko, nicméně v tomto textu se namísto pojmu mentalita přidržím pojmu ideologie, který nebude chápán v takovém smyslu, v jakém s ním pracoval autor teorie autoritativních režimů Juan Linz ${ }^{6}$ - s pojmem ideologie bude v tomto př́padě pracováno jako s pojmem označující národní, respektive státní myšlenku či ideu, která má být základem identity národa/státu. A právě takto pojatá ideologie bude jedním z předmětů zájmu předkládaného textu.

Rozsah tohoto článku samozřejmě neumožňuje vývoj vzájemných vztahů za posledních téměř dvacet pět let rozebrat do každého detailu, zahrnout do něj jakoukoli důležitou událost nebo prezentovat postoje celé řady (byt' zásadních) aktérủ. Cílem textu je proto představit stručný náčrt toho, jak se vzájemný vztah proměňoval v období, ve kterém se vystřídali dva patriarchové a tři prezidenti. Naznačena bude zejména dynamika vzájemných vztahů a některé konkrétní projevy tohoto vztahu - např́klad volební podpora církve vybraným kandidátům. Po stručném náčrtu tohoto vývoje bude druhá část článku věnována jedné konkrétní události - vystoupení Pussy Riot v moskevském chrámu Krista Spasitele -, která dobře ukazuje několik různých rozměrů jednak reálného propojení státu a církve v podmínkách autoritativního režimu v současném Rusku, zároveň dobře ukazuje to, jakým způsobem jednotliví klíčoví aktéři přispívají k reprodukci veřejného diskurzu, který toto vzájemné propojení legitimizuje a vyzdvihuje jako něco, co je pro ruský stát a ruský národ ideálním stavem. Text byl zpracován za použití jak odborné literatury, tak - vzhledem k aktuálnosti tématu a k tomu, že řada zmiňovaných událostí a výroků není v odborné literatuře zatím reflektovaná - zpravodajství a dalších internetových zdrojů.

\section{Vztahy státu a církve v období patriarchátu Alexije II.}

Na počátku 90. let se přístup státu k církvi nesl do velké míry v duchu omluv církvi ze strany státu za její postavení v předchozích desítkách let. Církev v této době zažívá jakési znovuzrození, začalo vznikat mnoho církevních obcí, stavěla se řada nových (nebo obnovovalo mnoho zaniklých) klášterů, kostelů ${ }^{7}$ atd. $\mathrm{V}$ tomto počátečním období se také vzájemný vztah nesl v duchu principů odluky státu a církve - stoupencem tohoto principu byl v této době dle svých proslovů a rozhovorů i patriarcha Alexij II., ${ }^{8}$ tedy představitel, který jen o několik let později přivedl církvi k těsnému spojenectví s politickou mocí.

Na druhou stranu již od počátku existence nového ruského státu si církev nárokovala vliv na společnost a patriarcha církev stylizoval do role aktéra, který má společnost nacházející se v komplikované postkomunistické situaci, která byla spojená s hledáním

6 V českém prostředí např. Ptáčník, Jan:. Perspektivy využití Linzovy metodologie pro výzkum nedemokracie. Central European Political Studies Review, 2012, 12, s. 326-329.

7 Včetně moskevského chrámu Krista Spasitele.

8 Krasikov, Anatolij: Globalizacija i pravoslavije. In: Religija i globalizacija na prostorach Evrazii. Eds. A. Malašenko, S. Filatov. Moskva, s. 46. 
vlastní nové identity, ekonomickým úpadkem a úpadkem prestiže celého státu, ${ }^{9}$ pomoci stabilizovat. V ruském pravoslaví měla být nabídnuta nová konzistentní sada hodnot a idejí namísto právě zavrženého komunismu. Ostatně v tomto, tedy ve vytvoření jakési nové národní/státní ideologie, byla církev podporovaná státem ${ }^{10}$ a Alexij II. často opakoval, že v Rusku existuje historická tradice, díky které je pravoslaví jedním z pilíruo ruské státnosti. Ze strany Alexije II. tedy od počátku zazníval apel na návrat k těmto historickým tradicím, který byl zároveň do velké míry doprovázený odporem k přijímání hodnot západních - ve většině projevů byl Západ pojímán jako nositel negativních hodnot, které by Rusko nemělo přebírat. V tomto ohledu se patriarchův postoj podobal postoji řady vlivných intelektuálů. ${ }^{11}$ Po krátkém počátečním období tedy nastává stav, ve kterém se z církve stává státem podporovaná instituce, která symbolizuje ztělesnění ruských hodnot, identity a ruské jedinečnosti oproti západu. Pravoslaví tedy rychle dostává politický náboj, církev a stát se postupně provazují a poslání církve se vedle náboženského záhy stává také společensko-politickým.

Díky tomuto postavení se od počátku církvi dostávalo podpory většiny existujících politických stran, ${ }^{12}$ politici (včetně bývalých komunistů) v čele s prezidentem Jelcinem začali navštěvovat církevní slavnosti a obřady a fotografie a reportáže z těchto akcí se u řady politiků staly důležitou součástí vlastní politické image. Církevní svátky se za přítomnosti politiků začaly přenášet v hlavních televizních kanálech a církev dostala své televizní pořady. Tento př́stup do médií pomáhal uplatňovat postavení církve.

Jeden z prvních okamžiků, kdy církev zasáhla do politiky, byly prezidentské volby v roce 1996, v nichž (ještě v době, kdy bylo Jelcinovo zvolení zcela nejisté - jeho podpora před volbami extrémně poklesla ${ }^{13}$ ) patriarcha a někteří další představitelé otevřeně vyjadřovali podporu Jelcinovi. Alexij II. také veřejně kritizoval ty duchovní, kteří podporovali jiné kandidáty. ${ }^{14}$

Zásadní dobou pro rozvoj vztahů státu a církve byly parlamentní a zejména prezidentské volby v letech 1999 a 2000. V př́ípadě parlamentních voleb se zdálo, že bude ze strany církve vyjádřena podpora stávajícímu premiérovi Jevgeniji Primakovovi a moskevskému starostovi Juriji Lužkovovi a jejich uskupení Vlast - Celé Rusko. ${ }^{15}$ Tato mož-

9 Toto bylo na počátku desetiletí často vystiženo výsměšnými konstatováními, že Rusko je jako „Burkina Faso s jadernými raketami“. Srov. Romancov, Michael: Nová studená válka mezi Ruskem a Západem. Acta Politologica, 2009, 1, s. 89.

10 Ščedrin, Viktor: Iděologija i cerkov': 2010-e. Gefter, 30. 3. 2015 (http://gefter.ru/archive/14675, 19.11. 2015).

11 Např. Solženicyn, Aleksandr. „The Russian Question“ and the End of the Twentieth Century. New York 1995.

12 Je zajímavé, že výrazná podpora přicházela i od komunistů, kteří v církvi viděli spojence proti Západu a liberalismu. Postoj církve vưči komunistům se částečně proměnil ve druhé polovině 90 . let, kdy strana mírně oslabila. Postoj pak byl zcela přehodnocen po nástupu Vladimíra Putina k moci, kdy církev vůči opozici zaujímá negativní postoje.

13 Holzer, Jan: Politický systém Ruska. Brno 2001, s. 41.

14 Papkova, Irina: Russian Orthodox concordat? Church and state under Medvedev. Nationalities Papers, 2001, roč. 39 , č. 5 , s. 668 .

15 Tato strana byla sice „proprezidentská“, ale zároveň „protijelcinovská“. Srov. např. Holzer, Jan: Politické strany Ruska. Hledání identity. Brno 2004, s. 175-176. 
ná podpora by souvisela s obdobnou politickou orientací, protizápadním směřováním nebo i s tím, že moskevský magistrát výrazně podporoval pravoslavnou církev. K částečné změně došlo poté, co byl premiérem po Primakovovi jmenován Vladimír Putin a co začala být formována prokremelská strana Jednota. ${ }^{16}$ Církev nakonec žádné ze soupeřících stran jasnou a přímou podporu nevyjádřila. Boris Jelcin roku 1999 abdikoval a moc byla prozatímně předána Putinovi. Zajímavá a nezvyklá je př́tomnost patriarchy při této abdikaci - Alexij II. tímto symbolicky požehnal změně moci a aktu dodal legitimitu.

Ihned po předání moci začalo pevné spojenectví patriarchy a úřadujícího prezidenta Putina, kteří toto spojenectví manifestovali např́íklad společným vystupováním na všech televizních kanálech. Ve volbách roku 2000 církev jednoznačně podpořila Putina a doporučila věřícím, aby se zúčastnili voleb a hlasovali pro „správného“ kandidáta. Se zvolením Putina do úřadu začíná ve vzájemných vztazích nová etapa, církev začíná podporovat veškeré kroky oficiálních státních míst. Spojenectví bylo symbolicky prokázáno ihned na začátku Putinova mandátu - sám Alexij II. po Putinově inauguraci sloužil bohoslužbu věnovanou novému prezidentovi a osobně mu požehnal. ${ }^{17}$

$\mathrm{V}$ roce $2008^{18}$ patriarcha Alexij II. umírá. Po jeho smrti prezident Medvěděv s premiérem Putinem konstatovali, že patriarchova smrt je pro Rusko velkou ztrátou. Putin navíc charakterizoval Alexije II. jako významného státního (tedy nikoli církevního!) činitele, který se výrazně zasadil o novou postkomunistickou státnost Ruska. ${ }^{19} \mathrm{Shrneme-li}$ období patriarchy Alexije II., můžeme říci, že navzdory sekulární povaze Ruska, která je zakotvená i v ruské ústavě, se z patriarchy stal významný aktér nejen v duchovní, př́ípadně kulturní a společenské sfére, ale zároveň významný aktér politický, který vstupoval a vyjadřoval se $\mathrm{k}$ většině politických témat a událostí. Společně s tím stoupla politická úloha i církve jako celku, ta začala spolupracovat s řadou oficiálních státních orgánů.

\section{Vztahy státu a církve v období patriarchátu Kirilla I.}

Po smrti Alexije II. byl do funkce patriarchy pod církevním jménem Kirill I. zvolen Vladimír Gundajev, zkušený církevní hodnostář, který vystřídal několik dủležitých církevních funkcí. Kirill navázal na dřivější činnost Alexije II. a ve své činnosti byl podporován mocenským Medveděvem a Putinem, kteří mu ihned po zvolení do funkce pogratulovali.

Kirill se, ještě jako metropolita, od počátku 90 let netajil svým názorem, že by církev měla hrát vưči společnosti a politice daleko aktivnější úlohu. Od počátku svého

16 Tamtéž, s. 175

17 Bičurin, Alexej: Blagoslovlenije na preziděnstvo. Nezavisimaja gazeta, 17. 5. 2000 (http://www.ng.ru/ facts /2000-05-17/1_blessed.html, 19. 11. 2015).

18 Na okraj doplňme, že v tomto roce proběhly také prezidentské volby, ve kterých církev podpořila kremelského kandidáta Medveděva.

19 NTV: Medveděv: končina Patriarcha - ogromnoje gore dlja strany, 2008 (http:/ / www.ntv.ru/novosti /145815/, 19. 11. 2015). 
patriarchátu se začal snažit jednak o větší politickou úlohu církve, zároveň o ovládnutí všech vnitro-církevních procesů - významné pozice začal obsazovat svými stoupenci. Kromě tohoto chování a také podoby proslovů - Kirill si nenechá ujít jediné důležité politické téma a k politickým otázkám se vyjadřuje snad častěji než k otázkám duchovním - dává Kirill také na odiv bohatství, ve kterém žije - pověstná je například kauza s patriarchovými hodinkami.

Kirill klade od začátku svého patriarchátu značný důraz na prosazení pravoslaví ve školách. Základy pravoslavné kultury (Osnovy pravoslavnoj kultury) jsou kurzem, který má nejen vzdělávat žáky o pravoslaví, ale zároveň má u školáků vytvářet sepětí s novou ruskou státní ideologií, jejímž základním tvrzením je to, že pravoslaví je něčím, co odlišuje Rusko od zkaženého Západu, a zároveň představuje konstitutivní prvek ruské státnosti a národa od okamžiku christianizace Rusi do současnosti. Součástí této ideologie je i přesvědčení o tom, že ruský lid je nositelem jedinečné civilizace, což Kirill ostatně tvrdil od začátku 90 . let. ${ }^{20}$

Kirill považuje v rámci ruské historické tradice za příznačnou symfonii, tedy propojení státu a církve. ${ }^{21}$ Toto stanovisko potvrzuje v řadě svých veřejných prohlášení, rozhovorů, vystoupení $\mathrm{v}$ mnoha pořadech federální televize, kde opakovaně vyjadřuje podporu krokům oficiálních státních představitelů, a to jak krokům v rámci vnitřní politiky, tak v rámci politiky zahraniční.

Prozatím poslední prezidentské volby proběhly v Rusku roku 2012 a jejich hlavním cílem bylo opět do prezidentské funkce dosadit tehdejšího premiéra Putina. Církev a řada jejích funkcionářu opět odsoudila opoziční kandidáty a podpořila Putina - např́klad prostřednictvím setkání církevních funkcionářů s Putinem, které bylo organizované patriarchou. S žádným dalším kandidátem se pravoslavní představitelé nesetkali. Podpora byla tedy zřejmá, ostatně stejně jako v př́ípadě parlamentních voleb rok předtím, nicméně Kirill v př́padě této prezidentské volby osobně přímou a doslovnou podporu nevyjádřil. I přesto v některých chrámech probíhala během bohoslužeb proputinovská otevřená agitace.

\section{Kauza Pussy Riot jako událost symbolizující rozměry vztahu státu a církve v období dua Putin-Kirill22}

Představme si nyní podrobněji již v úvodu slibovanou známou událost z roku 2012 - vystoupení skupiny Pussy Riot v moskevském chrámu Krista Spasitele -, která dobře

20 Ke kurzu více např. Köllner, Tobias: Patriotism, Orthodox religion and education: empirical findings from contemporary Russia. Religion, State and Society, 2016, č. 4, s. 366-386.

21 Zamysel Božij o čeloveke i svoboda voli: eschatologičeskaja perspektiva. RPC MP, 15. 11. 2005 (http://www.patriarchia.ru/db/text/57597, 19. 11. 2015).

22 Některé pasáže této kapitoly byly již dříve publikovány a do tohoto textu byly zařazeny po rozsáhlé úpravě a doplnění dalšími informacemi a pouze s laskavým souhlasem spoluautora původního textu. Srov. Kalinič, Petr a Naxera, Vladimír: Pussy Riot aneb Svéráz ruských marginálio. Mezinárodní politika, 2012, č. 10, s. 31-34. 
ukazuje reálné propojení státu a církve v době prezidentství Vladimíra Putina a Korillova patriarchátu a stejně dobře poodhaluje reprodukci diskurzu, který tento vztah legitimizuje. Tento relativně krátký incident (v reálu celá akce trvala cca 40 sekund, poté byly dívky zpacifikovány ochrankou) byl zamýšlen jako reakce na politickou angažovanost patriarchy Kirilla, který pravoslavné věřící vyzval k podpoře Putina v prezidentských volbách. V průběhu akce byla přednesena „punková modlitba“ s těmito slovy:

„Bohorodičko, Panno,

vyžeň Putina,

Putina vyžen̆

Černá róba, zlaté nárameníky.

Farnici se všichni plazí, aby se klaněli.

Přelud svobody na nebesich.

Gay pride poslán v okovech na Sibiř.

Hlava KGB, jejich hlavni svatý,

vede demonstranty do vězeni s eskortou.

Aby nejsvětějšího neurazily,

ženy musi rodit a milovat.

Do prdele, do prdele, do prdele.

Bohorodičko, panno,

staň se feministkou.

Církevni chvála prohnilým lidrưm,

kř́ž nesoucí procesí z černých limuzín.

Do školy za tebou přichází kazatel,

utikej na hodinu a dones mu penize!

Patriarcha Gund'aj věři v Putina,

lepši by bylo, kdyby ten čubči syn

věril v Boha.

Závoj Panny Marie masové

protesty nenahradi,

na demonstracích je Bohorodička s námi. “23, ${ }^{24}$

Členky Pussy Riot se věřícím za své vystoupení následně omluvily, ale zároveň odmítly svojí performanci, která se uskutečnila v téměř prázdném chrámu, interpretovat jako

23 Putna, Martin C.: Obrazy z kulturních dějin ruské religiozity. Praha 2015, s. 280.

24 Je ovšem třeba konstatovat, že českých překladů a interpretací jednotlivých slov existuje více. 
skutkovou podstatu trestného činu. Je zajímavé dodat, že samy zpěvačky charakterizovaly své vystoupení v tom smyslu, že bylo namířené proti církvi, ale nikoli proti věřícím a nelze jej v žádném případě považovat za rouhání. ${ }^{25}$ Toto odvozovaly i od toho, že se vystoupení odehrálo na místě, které je podle nich světské spíše než církevní. ${ }^{26}$

Patriarcha Kirill nevydal oficiální prohlášení po dlouhou dobu od vystoupení, ale řada dalších církevních představitelů vyjadřovala názor, že jde o rouhání. Zároveň ale konstatovali, že by měl čin Pussy Riot být řešen nikoli církevními, ale světskými orgány. Toto ukazuje na výrazné propojení církve a státu, který je dle své vlastní ústavy sekulární, tedy oddělený od církve, a neměl by z podstaty věci „rouhání prostřednictvím svých orgánů vůbec řešit. Slova o rouhání zazněla např́íklad z úst oficiálního mluvčího církve Vsevoloda Čaplina, který kromě rouhání hovořil zároveň i o trestném činu. ${ }^{27}$

Patriarcha Kirill nakonec akci komentoval v tom smyslu, že není možné takový čin bagatelizovat a považovat za nevinný vtip, je třeba jej tvrdě potrestat, v tomto ohledu hovořila i řada dalších prorežimních představitelů (srov. níže). Ostatně i podle prezidenta Putina bylo třeba dívky potrestat - povinností ruského státu je dle něj chránit pocity věřících ${ }^{28}$ Toto je opět zcela zarážející vzhledem k ústavou deklarované sekulární povaze Ruské federace.

Tři aktérky byly nakonec po pěti měsících vazby moskevským soudem, jehož průběh doprovázela řada kontroverzí a podezření o jeho nezávislosti (což ostatně není vzhledem $\mathrm{k}$ autoritativní povaze režimu nic překvapivého), uznány vinnými $\mathrm{z}$ „výtržnosti motivované náboženské nenávisti““ (dívky se rovněž dopustily „zločinného spiknutí za účelem hrubého narušení veřejného pořádku“) a odsouzeny ke dvěma rokům internace v nápravné kolonii. Dle prokurátora Alexeje Nikoforova navíc činy pachatelek prokázaly evidentní nenávist a nepřátelství vůči náboženství a „urazily Boha“. ${ }^{29}$

V souvislosti se společenskou a zejména politickou debatou po vystoupení Pussy Riot lze zmínit ještě přijetí zákona o hanobení pocitu věřících, který byl přijat roku 2013 a který ztělesňuje tento oficiální diskurz. Tento zákon je vzhledem k deklarované sekulární povaze státu velmi překvapivý, navíc umožňuje postihnout kde co, např́ílad i proticírkevní karikaturu umístěnou nikoli v církevním, ale i v čistě světském kontextu atd. Zákon má celkově ochránit spojenectví státu a církve před útoky zvnějšku.

Podívejme se nyní na to, jakým způsobem incident komentovali dva prorežimní intelektuálové a jakým způsobem poukazovali na propojení státu a církve. Symptomatickou je reakce geopolitika, filosofa a bývalého pracovníka KGB Alexandra G. Dugina, který kauzu Pussy Riot označil za akt informační války, jenž má za cíl destabilizaci Ruska, podkopání morální a psychické síly a podřízení státní suverenity mezinárodním silám.

25 Solodovnik, Svetlana: Dva naroda, dve cerkvi. Pro et Contra, 2012, č. 3, s. 32-61.

26 Tolokonnikova, Naděžda. Pussy Riot. Čto eto bylo? Moskva 2012, s. 58.

27 K jeho výrokům např. Čaplin, Vsevolod: Koščunstvo u Carskich vrat. Livejornal, 22. 2. 2012 (http://pravoslav-pol.livejournal.com/8714.html, 19. 11. 2015).

28 Putin, Vladimir: Intěruju RT, 2012 (https://www.youtube.com/watch?v=EmIOWrb51Yc, 19. 11. 2015).

29 K rozsudku viz např. iDNES.cz: Pussy Riot dostaly za výtržnost v pravoslavném chrámu dva roky, 17. 8.2012 (http://zpravy.idnes.cz/verdikt-pussy-riot-0o3-/zahranicni.aspx?c=A120807_132801_zahranicni_ts, 19. 11. 2015). 
Cílem této aktivity je diskreditace osoby Kirilla a nejen jeho, ale zároveň i celého posvátného institutu patriarchy. Dugin incident vnímá jako bezprecedentní útok na již zmiňovaný konzervativní rusko-byzantský ideál symfonie moci, který definuje jako elementární výraz kontinuity ruských dějin, s tím ostatně souhlasí i Kirill. Vystoupení Pussy Riot má podle Dugina znesvětit sakrální hierarchii ruské státnosti v čele s prezidentem Putinem. Toto Putinovo postavení je přitom logickým projevem oné zmiňované symfonie moci.

Celý incident je vnímán jak symptom návratu éry tzv. „výmarského Ruska“ - období nestability a socio-ekonomického a mocenského pádu Ruska v první polovině 90 . let. ${ }^{30}$ Kauza Pussy Riot je stavěna do kontextu konfrontace „spirituálního Ruska s tisíciletou tradicí“ a „degenerovaného Západu“, který zrelativizoval a zničil svou kulturní i náboženskou tradici. Toto ostatně odpovídá Duginovu geopolitickému vidění světa, kdy původní multipolarita byla nahrazena unipolaritou v čele s USA, povinností Ruska jako zásadní eurasijské mocnosti je přitom snažit se prosazování této unipolarity zabránit. ${ }^{31}$ Jen v tomto ohledu dodejme, že již po zvolení Kirilla do úřadu patriarchy se Dugin vyjádřil v tom smyslu, že očekává, že Kirill bude hájit pravoslavné hodnoty tím, že bude bojovat proti liberalismu a postmoderně neseným zdegenerovaným Západem.

K případu Pussy Riot je tak údajně nutné přistupovat velmi zodpovědně, nebot' se jedná o útok na „ortodoxní věčnost“ a o manifestaci „západního infiltrátu“ - lidí, kteří Rusko nenávidí, chtějí ho dobýt, pokořit a zničit. Jediným způsobem obrany je v tuto chvíli loajalita směřující k osobě prezidenta Putina, ${ }^{32}$ který reprezentuje posvátnou ruskou ideu spojenou s Ruskem jako Třetím Římem. Incident v chrámu Krista Spasitele je projevem globálního vydírání a důkazem probíhajícího duelu se Západem, který Rusko nesmí prohrát. Pokud by se tak stalo, zmizí poslední pozůstatky morálky, spirituality a řádu. Tradiční hodnoty budou nahrazeny destruktivními iluzemi liberálů a postmodernistů. Skupina Pussy Riot tak v reálu představuje „pátou kolonu“ Západu, který s Ruskem vede válku všemi možnými prostředky. Tato válka má kulturně i sociálně genocidní charakter a klíčem k identifikaci nepřítele je jeho angažovanost za propuštění Pussy Riot. Tito lidé jsou v nastávající konfrontaci schopní čehokoli. ${ }^{33}$

Dalším případem, kdy se Putinovi loajální a režimem podporovaný intelektuál aktivně vyjadřoval v neprospěch Pussy Riot a podporoval jejich tvrdé odsouzení, je Sergej

30 Srov. např. Nowak, Andrzej: Impérium a ti druzí. Rusko, Polsko a moderní dějiny východní Evropy. Brno 2010.

31 Srov. např. Dugin, Aleksandr G.: Osnovy geopolitiki. Moskva 1999³, také týž: The Eurasian Idea, 2004 (http: / / evrazia.info/modules.php?name=News\&file=article\&sid=1884, 19. 11. 2015), případně Kalinič, Petr a Naxera, Vladimír: Politická teorie a geopolitika A. G. Dugina. Rexter, 2011, 9, s. 31-56, nebo Naxera, Vladimír. Geopolitická teorie A. G. Dugina. In: Bezpečnostné fórum 2012. Zborník príspevkov z V. medzinárodnej vedeckej konferencie. II. zväzok. Banská Bystrica 2012, s. 441-250.

32 Ostatně loajalita vůči Putinovi je něco, co je součástí Duginových názorů dlouhodobě. Můžeme připomenout např́íklad známý Duginův citát: „Odpůrci Putina a jeho kurzu již neexistují, ale pokud se ještě vyskytují, tak jsou to psychicky nemocní lidé a je třeba je podrobit dispenzarizaci. Putin je všechno, Putin je absolutní, Putin je esenciální. "Srov. Šerendovič, Viktor: Putin - vse, Putin absoljutěn, Putin nězamenim, 2007 (http://www.inosmi.ru/inrussia/20070926/236828.html, 19. 11. 2015).

33 K Duginovu postoji vůči Pussy Riot viz např. Dugin, Aleksandr G.: Aleksandr Dugin: Pussy Riot's Global Blackmail, 2012 (http://www.youtube.com/watch?v=IxhxRyeX8tY, 19. 11. 2015). 
A. Markov, prorektor Ruské ekonomické univerzity a s Kremlem úzce propojený politický komentátor, bývalý poslanec Dumy za stranu Jednotné Rusko, bývalý pracovník KGB a také člen „Prezidentské komise RF proti pokusům o falsifikaci historie, jež jsou na újmu ruským zájmům“, která existovala v letech 2009-2012. Používanou argumentací se Markov v některých aspektech blí̌zi názorům Duginovým, zejména v otázce ohrožení Ruska mezinárodním spiknutím, ve kterém kromě obligátního Západu figurují i „,neposlušné“ státy tzv. blízkého zahraničí. Markov aktivně vystupuje ve prospěch „ruské imperiální velikosti a integrity“ a je známý kvůli své kritice historiků z bývalých svazových republik, kteří se kriticky vyjadřují k nadvládě Moskvy. Takto „proslul“ mimo jiné svým postojem vůči historikům zkoumajícím katyňský masakr, kteří podle něj „deformují a reviduji“ dějiny. Rovněž obvinil autory dějepisných učebnic v řadě postsovětských zemí, že historii vztahů s Ruskem vykreslují negativně a jsou vůči Rusku ideově předpojatí.

Akce Pussy Riot v chrámu nebyla podle Markova pouhým nerozvážným činem, za který by ze strany Putina stačilo „otcovské pokárání nerozvážných dívek“, ale součástí globální konspirace proti Rusku a ruské ortodoxní církvi. V souladu s touto interpretací vystoupení street-artové skupiny se Markov domnívá, že prezident Putin měl za povinnost zejména ochránit Ruskou federaci před zákeřným spiknutím. Pokud by byl trest Pussy Riot prominut (nebo byl př́liš shovívavý), pravoslavní věřící by měli oprávněnou obavu, že se např́ště stanou obětí ještě horšího rouhání, než k jakému došlo v chrámu Krista Spasitele ${ }^{34}$ - tento akt by pak údajně nemusel být veden podobným způsobem, jakým bylo ono chrámové vystoupení, ale realizován vojsky NATO, prrípadně „teroristy z Kavkazu“ nebo jinými nepřáteli ruského pravoslaví a ruského státu, což dle Markova jsou dvě věci úzce provázané.

Celý incident v chrámu Krista Spasitele je možné vnímat jako nepovedený protest, který měl za cíl poukázat na základní problémy ve vztahu státu a církve a celkově k nedostatku legitimity v distribuci politické a ekonomické moci v současném Rusku. Text „punkové modlitby“ upozorňuje na (re)inkorporaci církve do mocenských struktur formálně sekulárního státu nebo na fakt, že velká část ruských elit, které k moci přivedl Vladimír Putin, je tvořena důstojníky bývalé KGB (jejímž agentem byl ostatně podle některých zdrojů i samotný patriarcha), respektive širší skupinou tzv. silovikủ. ${ }^{35}$

Je zajímavé, že dřívější vystoupení Pussy Riot v Jelochovském chrámu bylo zcela ignorováno (mediálně i soudně), avšak performance v chrámu Krista Spasitele byla tvrdě potrestána. $V$ této souvislosti je nezbytné stručně zmínit symbolický význam tohoto chrámu, který je největším pravoslavným kostelem na světě a hlavním chrámem ruské ortodoxní církve. Chrám byl otevřen v roce 1883 za vlády bigotního cara Alexandra III.

34 Týden.cz: Proč nelze omilostnit punkerky z Pussy Riot, 17. 8. 2012 (http://www.tyden.cz/rubriky/zahranici/ rusko-a-okoli/proc-nelze-omilostnit-punkerky-z-pussy-riot_243235.html, 19. 11. 2015).

35 Silovici, tedy zástupci silových struktur, jsou zřejmě nejvýznamnější mocenskou skupinou současného Ruska. Můžeme přitom hledat dvě př́ičiny jejich vzestupu - jednak kontakty prezidenta Putina z období jeho angažmá v rámci KGB a jednak s Putinovým důrazem na řád a stabilitu, který vedl k postupnému protěžování silových struktur (přičemž valná většina jejich hlavních aktérů je spojena se silovými strukturami již před rozpadem SSSR). Leichtová, M.: Pod maskou medvěda, s. 110. 
Po bolševické revoluci se však stal nepohodlným a v roce 1931 byl vyhozen do povětří, aby uvolnil místo pro výstavbu megalomanského Paláce sovětů. Chrám byl znovu postaven až v letech 1994-2000. Nejde tedy o starobylou památku, navíc naprostá většina plochy chrámu se využívá komerčně i pro činnosti s církví spojené jen okrajově či vůbec.

Závěrem dodejme, ona „punková modlitba“, tím, jak „urazila věrící“ se jen těžko vyrovná proticírkevním akcím bývalých struktur SSSR, ze kterých se rekrutovaly současné „zbožné“ elity, které glorifikují sovětskou epochu (např. banalizují její zločiny nebo opomíjejí kontroverzní fakta), ale zároveň zdůrazňují domnělou kontinuitu a vzájemnou propojenost světské a duchovní moci. Mediální pozornost věnovaná kauze a citlivý kontext historie chrámu tak ve výsledku vytvořily paradoxní situaci, kdy lidé z bývalých silových struktur hystericky reagují na útok proti církvi, která dnes tvoří oporu ruské identity, ale kterou tito lidé ještě nedávno měli na seznamu „kontrarevolučních“ antisystémových elementů.

\section{Závěrečná poznámka}

Záměrem tohoto textu bylo představit podobu a vývoj vzájemného vztahu státu a církve v postsovětském Rusku. Tento vztah prošel zásadní proměnou - úplný začátek 90. let byl ve znamení oddělení státu a církve, stát se navíc svým postupem vůči církvi snažil o nápravu křivd komunistické minulosti. Toto se ovšem velice rychle změnilo a nejpozději v polovině 90 . let se z církve stává instituce, která se napojuje na oficiální státní představitele, vyjadřuje jim volební podporu a dodává legitimitu jejich politickým rozhodnutím. Výsledkem je, že ve většině zásadních otázek hlásají prezident, premiér a patriarcha obdobné/stejné názory. Tato konstelace vydržela za všech dvojic prezident-patriarcha, které se vystř́ídaly - Jelcin-Alexij, Putin-Alexij, Medveděv-Alexij, Medveděv-Kirill a konečně Putin-Kirill. Zejména spojenectví Putina a Kirilla dalo církvi výraznou politickou úlohu. Pro demonstraci tohoto spojenectví byla vybrána zejména kauza Pussy Riot. ${ }^{36}$

V současné době ve svých oficiálních stanoviscích ruská pravoslavná církev prezentuje jasný patriotismus, který je spojen s odmítnutím všeho západního, včetně liberalismu, respektive liberálně demokratického zřízení v takové podobě, v jaké jej známe ze západních politických režimů, což ovšem koresponduje s již zmíněnými koncepty řízené a suverénní demokracie, se kterými operuje Vladimír Putin. Církev tak svým konáním pomáhá upevňovat a legitimovat činnost autoritativního režimu, který v současném Rusku existuje.

36 Vedle této kauzy by bylo možné vzájemné vztahy ilustrovat na celé plejádě dalších událostí, nicméně omezený prostor časopiseckého článku toto neumožňuje. 


\section{Transformations of the Relationship between the State and the Russian Orthodox Church in Post-Soviet Russia - selected Issues and Topics}

The intention of this text was to introduce the path after the collapse of the USSR and the fall of the communism unfolded in the relations between the new Russian state and the orthodox church, or that year of 1991 ended a long period, in which was from the state persecuted - the period after the collapse of the USSR was for the church a period of made of the renaissance. In the early 90 's. years might seem, that in new conditions it comes to setting the „normal“ form of the relations of church and state, which we know from a number of other countries. This idea, however, quickly disappeared and by the mid 90's. years of the church becomes an institution which connects to the official state representative, expresses them electoral support and adds to the legitimacy of their political decisions. The result is that in most of the fundamental questions proclaim the president, prime minister and patriarch of a similar/the same views. The result is that in most of the fundamental questions proclaim the president, prime minister and patriarch of a similar/the same views. This constellation lasted for all pairs of the president-the patriarch, which was replaced by. In particular, the alliance of Putin and Kirill gave the church a substantial political role. For a demonstration of this alliance was chosen in particular the case of Pussy Riot. The well shows a number of different dimensions of both the real connection of church and state in the conditions of authoritarianism in contemporary Russia, at the same time well illustrates the way in which individual key actors contribute to the reproduction of public discourse, this interconnection legitimizes and highlights as something that is for the Russian state and the Russian nation to an ideal state. Currently in its official opinions of the Russian orthodox church presents a clear patriotism, which is associated with the rejection of everything western, including the liberalism of the liberal democratic establishment - entirely in conformity with the rejection of this model of government from the party of president Putin. The church then your doing it helps to consolidate and legitimize the activities of an authoritarian regime, which in present Russia there are. 